\title{
The influence of technical characteristics of wood milling tools on its wear performance
}

\author{
Regita Bendikiene $^{1}$ (1) $\cdot$ Gintaras Keturakis $^{2}$
}

Received: 3 February 2017 / Accepted: 1 July 2017 / Published online: 9 August 2017

(C) The Japan Wood Research Society 2017

\begin{abstract}
Influence of technical and chemical characteristics of industrial wood milling tools on its wear was analysed. Four tools of different manufacturers were subjected to the research. Lithuanian oak wood was chosen for the research as a reference material. Behaviour of cutting tools was assessed on the adopted industrial thickness planer SR3-6 with cutting speed of $31 \mathrm{~m} / \mathrm{s}$. Wear performance was evaluated on milling the specimens until $3200 \mathrm{~m}$ of true cutting length. Summarising achieved results, the following can be stated: chemical composition of tool and heat treatment schedule has great impact on the tool edge wear. The highest wear resistance was reached on testing tools made of CT01M-LA2; tools made of highalloyed tool steel 8Х6НФT have presented the highest cutting edge radius and edge recession in each type of test as compared with tools made of high-speed tool steels Z80WCV18-04-01/18-0-1 and HS18-0-1, respectively. All these tools are suitable for oak wood processing. The highalloyed tool steel shows similar wear performance as highspeed tool steels.
\end{abstract}

Keywords Wood milling - Oak wood - Wear of tool . Wear resistance

Regita Bendikiene

regita.bendikiene@ktu.lt

1 Department of Production Engineering, Faculty of Mechanical Engineering and Design, Kaunas University of Technology, Studentu Str. 56, 51424 Kaunas, Lithuania

2 Department of Materials Engineering, Faculty of Mechanical Engineering and Design, Kaunas University of Technology, Studentu Str. 56, 51424 Kaunas, Lithuania

\section{Introduction}

Milling process is one of the most widely used processes in wood and wood-based materials processing. Strehler et al. [1] and Hernádez-Castaneda et al. [2] show that alongside the quality of machined wood surface, the tool lifetime is an essential question in the industrial complex wood treatment process. Wood is readily available heterogeneous material with plenty of varieties, which is used in the furniture, packing, building constructions, beam flashings, flooring and panelling, window frames. The majority of wood processing companies specialise in the manufacture of planed-milled products. According to Horman et al. [3] and Vobrouček [4] during processing of wood by planning milling, the key point is to ensure high-quality machined surface with low processing costs; however, it is impossible to attain without analysis of various properties and technological parameters: wood moisture, thermal effects, cutting and feed speed, proper tool selection, toll geometrical parameters, toll material, etc. Another very important point in wood processing is to know which material would be machined: different process conditions are necessary for each species of wood to reach optimal results, wherefore it is not possible to explore just one type of cutting tool to achieve the best efficiency of process and high quality of products. A good thermal conductivity of the tools is essential in wood processing, because no cooling can be used in this process; it was analysed by Strehler et al. [5] and Costes et al. [6]. Temperature of the cutting tool affects the tool cutting edge blunting and wear, because the primary properties of tool material such as hardness, fracture toughness and chemical stability degrade on rising tool's temperature [7]. The heat generated during cutting process negatively affects the quality and accuracy of the product, herewith the life time of tool. 
Great demand of today's wood industry has resulted in intense development of the cutting tools, which unfortunately do not always have characteristics allowing a complete exploitation of the machinery. It is evident that the main problems in wood industry arise from differences in physical and chemical properties between wood and metal [8, 9]. Good machinability of wood allows high cutting and feed speed, herewith natural wood contains some water, which makes tooling very corrosive. Natural defects of wood cause blunting of tool edges, so extremely hard brittle materials are not suitable in this case. Hardened steels, high-speed tool steels, stellites, tungsten carbide and polycrystalline diamond tools have been used recently in wood transformation. The most common of them are alloyed tool steels and high-speed tool steels, because of their sufficient wear performance and relatively low cost, herewith sintered carbides, polycrystalline diamond tools, different antiwear multilayer coatings have been used recently [10]. The dominant wear of wood cutting tool is abrasion; however, erosion of tool material and blunting of its edges, which limits possibilities of tool application, can be observed. It was stated in the majority of works that final quality of wood products depends on correct choice of cutting tool type, cutting conditions and tool performance; selection of appropriate tool material for a certain application is directly influenced by the characteristics of material to be machined [11, 12]. As one of the major properties of final wood products, surface roughness greatly depends on the anatomic characteristics of wood, direction of wood grain and cutting tool characteristics [13, 14].

Different types of wood milling tools are used in industry: solid tools [made of alloy tool steel (SP), highalloyed tool steel (HL) or high-speed tool steel (HS)] and built-on hard alloy blades or different high wear resistance coatings. Shank of built-on tool is made of high carbon or alloy tool steel, while cutting edge is produced of stellites (ST) or plates of tungsten carbide (HW). The cutting edge of more advanced tools is made of polycrystalline (PKD) or monocrystalline (MKD) diamonds. Solid cutting tools are generally used for natural wood milling, planning and profiling contain chromium $(\mathrm{Cr})$ as the main alloying element. Chemical composition of tool steel plays an essential role in both tool performance and final quality of wood product.

Batch of HS tool steels is designed to be used particularly for making of cutting tools. In the wood cutting industry, the milling speed is very high and no cooling can be applied, so the ability to maintain the hardness and wear resistance at elevated temperatures (the property known as red hardness) is the main reason why those tools are widely used. Basic alloying elements ensure above-mentioned properties of tool. Tungsten (W) has an ability to form hard abrasion-resistant particles; it induces red hardness and improves hardenability. $\mathrm{Cr}$ easily combines with carbon (C) creating hard and high wear resistance chromium carbides, at the same time giving to the substance heat resistivity. $\mathrm{Cr}$ and nickel (Ni) content in the solid tool guarantees high enough corrosion resistance which is necessary for such a type of tooling. Vanadium (V) reduces the sensibility of steel to overheating, increases heat conductivity, and stimulates homogeneous distribution of carbide phase which can cause crumbling of cutting edges. Molybdenum (Mo), in the same way as $\mathrm{Cr}$, creates carbides very easily; the presence of this element in the steel composition helps to create fine-grained structure and increase hardenability; therefore, this chemical element presents in almost all HS steels, and it also increases the tensile strength at elevated temperatures.

SP and HS steels are used to produce wood milling tools, sawmills and other tools for wood processing machines. Tools made of SP steels are suitable for processing of both wet and dry timber, while high HS steels are used exclusively for dry woods [15]. Almost all SP and $\mathrm{HL}$ are rich in $\mathrm{Cr}$, which increases hardenability of steel, initiates formation of special carbides on hardening, either increases secondary hardness and heat resistance of steel; chromium carbides formed during treatment reduce wear of tool.

HS steels are used for manufacturing of wood cutting tools which heat up during process; wear resistance of this kind of steel is very high. High heat resistance is ensured by content of $\mathrm{W}, \mathrm{Mo}, \mathrm{V}$ and cobalt $(\mathrm{Co})$ in the steel composition; using this type of tools operation cutting speed is much higher than using SP steels [16].

The objective of this study is to test and compare wear behaviour of four wood millings tools from different suppliers, to analyse influence of its chemical composition and distribution of carbide phase in the microstructure on the tool edge recession and wear performance, while milling comparatively hard oak wood specimens on an industrial thickness planer with constant cutting speed and different feed rates.

\section{Materials and methods}

For the experimental analysis, four standard wood cutting tools from different suppliers made of SP steel and HS steels were chosen. Standard grades and chemical composition presented by suppliers are indicated in Table 1.

All cutting tools under the experiment were strait sharpened; its edges convergence was achieved by grinding procedures of wood cutting tool done by suppliers. 
Table 1 Chemical composition of standard wood cutting tools

\begin{tabular}{lllll}
\hline Chemical composition (wt $\%)$ & \multicolumn{5}{l}{ Wood milling tools } & \\
\cline { 2 - 5 } & No. 1 & No. 2 & No. 3 & No. 4 \\
& 8 X6HФT OTK-14 & ESS-HSS18 & HS 18 Y 28 & CT01M-LA2 \\
\hline $\mathrm{C}$ & $0.80-0.90$ & $0.75-0.83$ & $0.70-0.78$ & $0.73-0.83$ \\
$\mathrm{Si}$ & $0.15-0.35$ & $\leq 0.50$ & $\leq 0.45$ & $\leq 0.50$ \\
$\mathrm{Mn}$ & $0.15-0.40$ & $\leq 0.40$ & $\leq 0.40$ & $\leq 0.40$ \\
$\mathrm{Ni}$ & $0.90-1.30$ & - & - & - \\
$\mathrm{S}$ & $\leq 0.03$ & $\leq 0.03$ & $\leq 0.03$ & - \\
$\mathrm{P}$ & $\leq 0.03$ & $\leq 0.03$ & $\leq 0.03$ & - \\
$\mathrm{V}$ & $0.30-0.50$ & $1.00-1.30$ & $1.00-1.20$ & $0.90-1.20$ \\
$\mathrm{Ti}$ & $0.05-0.15$ & - & - & - \\
$\mathrm{Cr}$ & $5.00-6.00$ & $3.50-4.50$ & $3.80-4.50$ & $3.50-4.50$ \\
$\mathrm{Mo}$ & $\leq 0.20$ & $\leq 1.00$ & - & $\leq 1.00$ \\
$\mathrm{~W}$ & $\leq 0.20$ & $17.2-18.7$ & $17.5-18.5$ & $17.2-18.7$ \\
$\mathrm{Co}$ & - & - & - & $\leq 1.00$ \\
\hline
\end{tabular}

Accurate dimensions of tools: length L, width B and thickness $\mathrm{S}$ were measured using electronic calliper with the accuracy of $\pm 0.001 \mathrm{~mm}$. Accuracy of sharpness angle $\beta$ was ensured by using universal protractor Vogel No. 4443 with $5^{\prime}$ accuracy. Tools were weighted on electronic scales with an accuracy $\pm 0.01 \mathrm{~g}$ for determination of density. Hardness measurements were accomplished on the tools surface along the tool edge using Rockwell tester TK-2 with diamond indenter. The stylus tip surface roughness tester, profilometer Mahr MarSurf PS1 (the radius of its diamond tip was $2 \mu \mathrm{m}$, measurement angle $90^{\circ}$, and scanning length was $5.6 \mathrm{~mm}$, cutoff filter $0.8 \mathrm{~mm}$ ), was used for measurement of average roughness $R_{\mathrm{a}}$, mean peak-to valley height $R_{\mathrm{z}}$, and maximum roughness $R_{\text {max }}$; 5 values of roughness were taken and average presented. The surface roughness was measured in the longitudinal direction at the interval of $10 \mathrm{~mm}$, so 5 measurement positions in total were defined for each cutting tool on the rake and clearance face. The surface evaluation was performed starting from cutting side. Parameters of cutting tools and cutting tool geometry and location of measurements are presented, respectively, in Table 2 and Fig. 1.

Cutting tools microstructure and its morphology were determined using optical microscope Carl Zeiss LM 10. Specimens for the analysis of microstructure were made from each of wood cutting tools, then side surfaces were grinded, and examined. The scheme of specimens cutting position is presented in Fig. 1a.

Oak wood (Quercus robur) grown in Lithuania was chosen for the testing of cutting tool performance; specimens with dimensions of $100 \mathrm{~mm} \times 45 \mathrm{~mm} \times 1000 \mathrm{~mm}$ $(\mathrm{R} \times \mathrm{T} \times \mathrm{L})$ were prepared avoiding all the defects of natural wood. The number of annual rings per $1 \mathrm{~cm}$ was counted up on the end section of specimens. Moisture tester
Gann Hydrometter Compact A was used for the estimation of average moisture content (accuracy $\pm 1 \%$ ). Finally, for the determination of wood density samples with dimensions $20 \mathrm{~mm} \times 20 \mathrm{~mm} \times 30 \mathrm{~mm}(\mathrm{R} \times \mathrm{T} \times \mathrm{L})$ were produced, and were scaled on electronic balance (AND HF-12006 GF; accuracy $\pm 0.01 \mathrm{~g}$ ). Testing conditions were the same for all specimens: ambient temperature $18 \pm 2{ }^{\circ} \mathrm{C}$, relative air humidity-60 $\pm 5 \%$, when physical characteristics of oak wood samples were as follows: moisture content -9.50 to $10.4 \%$, number of annual rings per $1 \mathrm{~cm}-5.07$ to 5.25 , and density -518 to $570 \mathrm{~kg} / \mathrm{m}^{3}$.

The behaviour of standard wood milling tools was assessed on the adopted for the particular experiments industrial thickness planer SR3-6 according to the scheme of longitudinal milling (Fig. 2). Longitudinal milling is the most frequently used method to obtain flat surfaces in wood processing industry [17-19]. This type of operation ensures high surface quality. Wood specimens were processed by cutting speed $\left(v_{\mathrm{c}}\right) 31 \mathrm{~m} / \mathrm{s}$ with four different feed speeds $\left(v_{\mathrm{f}}\right): 3.00,6.00,9.00$ and $12.0 \mathrm{~m} / \mathrm{min}$. Average chip thickness was alternated changing feed per one insert $\left(f_{\mathrm{z}}\right)$ : $0.50,1.00,1.50,2.00 \mathrm{~mm}$. Wear performance was evaluated on milling the specimens until $3200 \mathrm{~m}$ of cutting length.

Tool geometry was analysed by alternations of cutting edge radius $\rho(\mu \mathrm{m})$, and edge recession $A_{\mu},(\mu \mathrm{m})$ of tools [20-23].

Values of cutting edge radius were determined applying lead impression method using optical tool measurement microscope of 2nd accuracy class (GOST 9038-80) and digital camera with resolution $640 \times 480$. Edge radius values were registered at the intervals of true cutting length $L$ which is the cutting way of tool in the wood: $0,50,100$, $150,200,400,800,1200,1600,2400$, and $3200 \mathrm{~m}$ in five places and average values were analysed; error of 
Table 2 Parameters of wood cutting tools

\begin{tabular}{|c|c|c|c|c|}
\hline \multirow[t]{2}{*}{ Parameters } & \multicolumn{4}{|l|}{ Wood milling tools } \\
\hline & No. 1 & No. 2 & No. 3 & No. 4 \\
\hline Designation by supplier & 8Х6НФТ ОТК-14 & ESS-HSS18 & HS 18 Y 28 & CT01M-LA2 \\
\hline Standard designation & 8Х6НФТ & Z80WCV 18-04-01/18-0-1 & HS 18-0-1 & HS 18-0-1 (B18) \\
\hline \multirow[t]{2}{*}{ Standard } & GOST 5950-73/ & NF A 35-590(92) & DIN 1.3355/ & UNI 2955-82 \\
\hline & DIN-EN 847-1 & ISO 4957 & ISO 4957 & ISO 4957 \\
\hline Dimensions (mm) L/B/S (Fig. 1) & $60 / 40 / 3$ & $60 / 35 / 3$ & $60 / 35 / 3$ & $60 / 30 / 3$ \\
\hline Tool geometry & \multicolumn{4}{|c|}{ Clearance angle $\alpha 20 \pm 5^{\prime}$, sharpness angle $\beta 40 \pm 5^{\prime}$, rake angle $\gamma 30 \pm 5^{\prime}$, cutting angle $\delta 60 \pm 5$} \\
\hline Mass (g) & 54.2 & 51.7 & 40.8 & 41.8 \\
\hline Density $\left(\mathrm{kg} / \mathrm{m}^{3}\right)$ & 7360 & 8119 & 8092 & 8144 \\
\hline Hardness (HRC) & 57 & 61 & 61 & 61 \\
\hline \multicolumn{5}{|l|}{ Surface roughness $(\mu \mathrm{m})$ (Fig. 1) } \\
\hline Rake face $R_{\mathrm{a}} / R_{\mathrm{z}} / R_{\max }$ & $0.518 / 3.35 / 5.18$ & $0.281 / 1.79 / 2.92$ & $0.251 / 2.11 / 2.98$ & $0.168 / 1.28 / 2.24$ \\
\hline Clearance face $R_{\mathrm{a}} / R_{\mathrm{z}} / R_{\max }$ & $0.600 / 4.11 / 4.90$ & $0.272 / 2.30 / 2.72$ & $0.285 / 3.39 / 4.23$ & $0.430 / 3.68 / 3.95$ \\
\hline
\end{tabular}

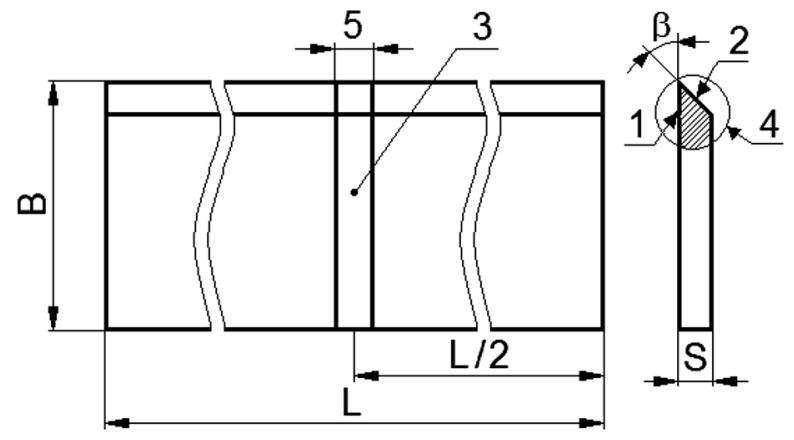

(a)

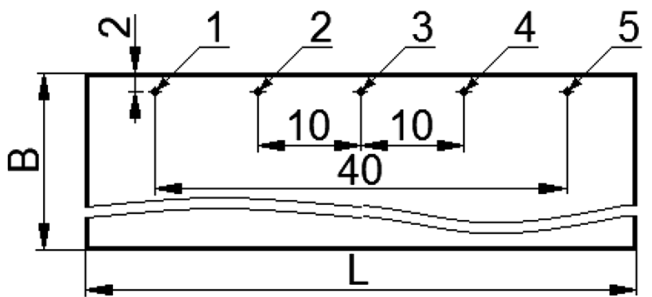

(b)

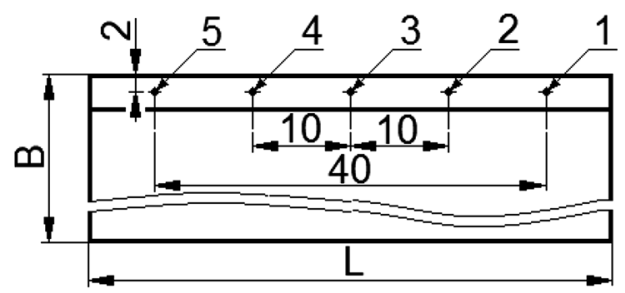

(c)

Fig. 1 Wood milling tool: a dimensions, 1 rake face, 2 clearance face, 3 specimen, 4 area examined using microscope; $\mathbf{b}$ rake face, $\mathbf{c}$ clearance face; 1-5 location of hardness and roughness measurements

measurements accuracy $\pm 2 \mu \mathrm{m}$. Reference surface was used for the optical visual observation of edge recession using microscope, and values were registered in the same intervals of cutting length.

Cutting power $P$ was figured out measuring available power and taking out an idle motion power. Available and idle motion power was measured using device K506 (GOST 8476-78, accuracy class 0.5 ) with the accuracy of $5 \mathrm{~W}$. The device was attached to the stand milling mechanism of electrical motor in parallel mode; an idle motion power was gauged before milling operation, while operating active power measured during whole process of milling.

\section{Results and discussion}

Four standard industrial tools from different suppliers were subjected to oak wood milling process. Analysing results of cutting edge radius, it can be stated that trend of wear mechanism of all milling tools is conventional; four main stages of wear are observed: first until $400 \mathrm{~m}$, secondfrom 400 to $800 \mathrm{~m}$, third-from 800 to $1600 \mathrm{~m}$, and the last-from 1600 to $3200 \mathrm{~m}$ of cutting length. The first stage gave the most intensive wear at all feeds per insert. In the next stage of process wear slowed down, and the growth of cutting edge radius decreased. Crumbling of edges was replaced by continuous and stable tribological 


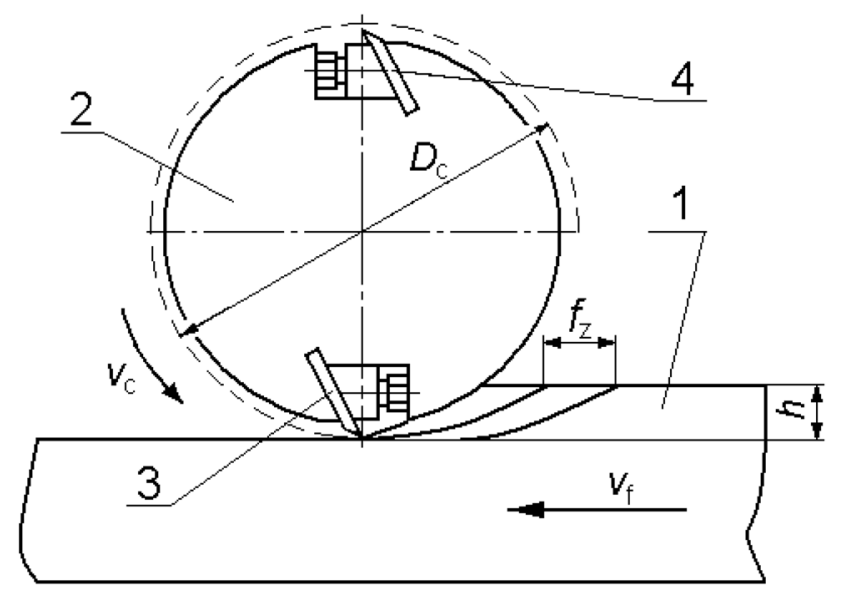

Fig. 2 Scheme of longitudinal milling: 1 specimen, 2 cutterhead, 3 examined cutting tool, 4 balance tool, $D_{c}$ cutting diameter $(103 \mathrm{~mm})$, $v_{c}$ direction of cutting speed, $v_{f}$ direction of feed rate, $f_{z}$ feed per insert, $h$ cutting depth $(2 \mathrm{~mm})$

wear, which was common for all tools. This stage revealed differences between wear of milling tools (Figs. 3, 4). Wear intensity slowed down in the third section of cutting length. Linear dependence of cutting edge radius on cutting length was observed in the last stage of experiment. Wear results in Fig. 3 show that cutting edge radius of cutting tool no. 1 made of high-alloyed tool steel $8 \times 6 \mathrm{H} Ф \mathrm{~T}$ increased the most. Wear performance of milling tool no. 4 made of high-speed tool steel HS 18-0-1 showed the best results at each feed per insert. Definitely it depends on chemical composition of tool: with very similar carbon content $(\sim 0.8 \%)$, material of tool no. 4 (Table 1) is richer in tungsten, which forms hard particles; hardness of these tools differs in few Rockwell hardness points (HRC).

More detail estimation of first stage of milling till the $100 \mathrm{~m}$ of cutting length points out the almost equal increment of edge radius for all milling tools; passing the limit of $100 \mathrm{~m}$ cutting tool no. 1 starts fray more intensively as compared with tools nos. 2, 3 and 4. On reaching $200 \mathrm{~m}$ of cutting path, difference in increment of cutting

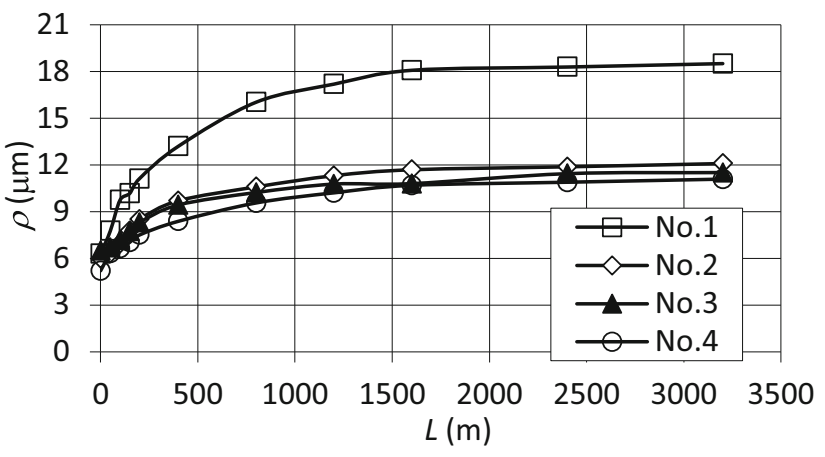

(a) edge radius exceeds $25.7 \%$ (nos. 1 and 4 ). This difference increases in all further stages of process and makes up $32.1 \%$ reaching $400 \mathrm{~m}, 36 \%-800 \mathrm{~m}$ of cutting length. Segment of cutting path from 1600 to $3200 \mathrm{~m}$ properly shows stable wear process where the values of edge radius are just slightly increased.

Tool no. 1 made of high-alloyed steel reaches hardness of $57 \mathrm{HRC}$ after hardening and low temperature $\left(250{ }^{\circ} \mathrm{C}\right)$ tempering. Microstructure consists of tempered martensite and carbides inclusions, which are uniformly distributed, just in some areas of tool coarse primary carbides and negligible linear distribution of carbides are observed (Fig. 5a).

Hardness of rich in tungsten high-speed tool no. 2 (61 HRC) is reached after hardening and tempering at $320^{\circ} \mathrm{C}$. Microstructure of tool consists of grains of austenite and martensite; the average size of grain is no. 11. Low tempering temperature for this type of steel does not allow to reach secondary hardness, wherefore steel does not possess high temperature resistance. Carbide phase is distributed uniformly; few coarse carbides can be seen (Fig. 5b).

Almost analogous structure of tool no. 3 (61 HRC) assures that these tools were subjected to the very similar schedule of heat treatment (Fig. 5c).

Wear test results of tools made of high-speed tool steel (nos. 2, 3, 4) are very similar; even hardness of these tools is the same-61 HRC, but the best wear performance was reached testing tool no. 4. Microstructural analysis revealed other important issue: tools nos. 2 and 3 were heat treated according to similar schedule; size of austenite grain in both is no. 11 (fine) according to the standard scale. Microstructure of tool no. 4 (Fig. 5d) differs: tool was tempered at higher temperature or required hardening temperature was not reached, because microstructure consists of tempered martensite and fine uniformly distributed disperse carbides. Course enough primary carbides and light high alloyed trails are observed in the structure that shows segregation of alloying elements in the tool blank.

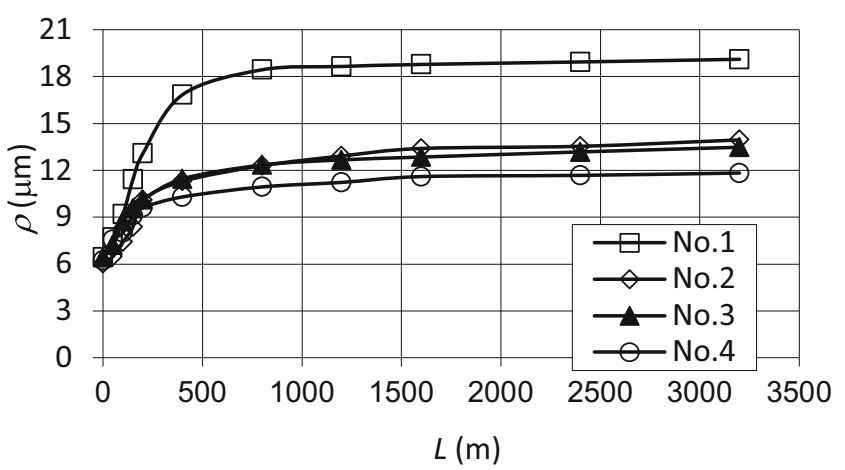

(b)

Fig. 3 Variation of cutting edge radius $\rho(\mu \mathrm{m})$ at different values of feed per insert $f_{\mathrm{z}}: \mathbf{a} f_{\mathrm{z}}=0.50 \mathrm{~mm}, \mathbf{b} f_{\mathrm{z}}=2.00 \mathrm{~mm}$ 


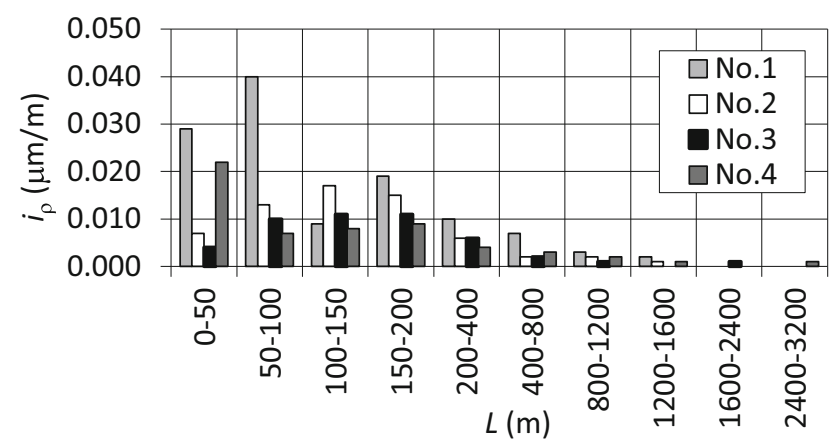

(a)

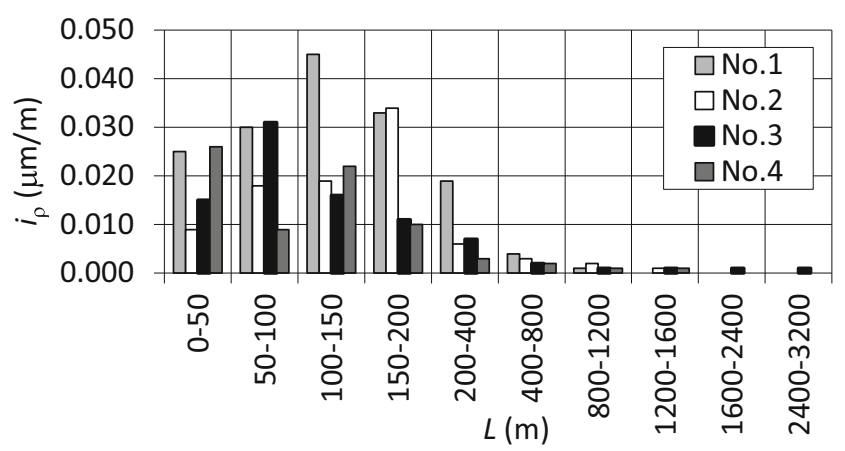

(b)

Fig. 4 Variation of intensity of edge recession $i_{\rho}(\mu \mathrm{m} / \mathrm{m})$ at different values of feed per insert $f_{\mathrm{z}}$ : a $f_{\mathrm{z}}=0.50 \mathrm{~mm}, \mathbf{b} f_{\mathrm{z}}=2.00 \mathrm{~mm}$
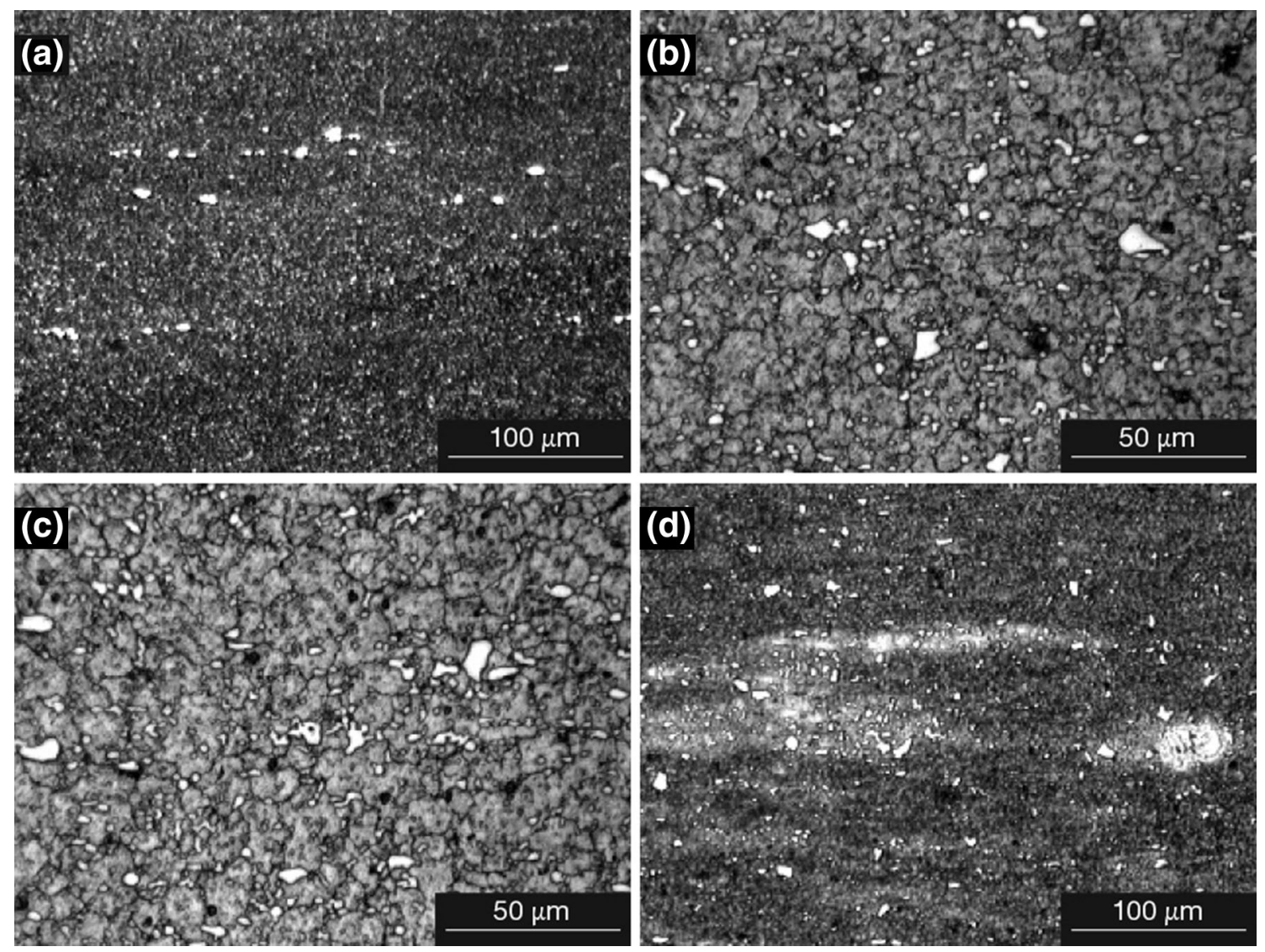

Fig. 5 Image of microstructure: a tool no. 1, b tool no. 2, c tool no. 3, d tool no. 4

Higher content of retained austenite presents in these segregation zones, showing that tempering process was incomplete; however, it did not affect wear resistance of tool-wear resistance of tool no. 4 is the highest. It is possible to maintain that regimes of heat treatment process influence wear behaviour of tools, but it was not studied in this research.

While evaluating influence of feed per insert on cutting edge radius, it is estimated that increasing the values of feed per insert radius of cutting edges increases as well. It is possible to set few periods in which wear process progresses according to different pattern. Firstly, influence of feed per insert is very low in the cutting length until $200 \mathrm{~m}$. Cutting edge radius increases approximately in $9.76 \%$, when feed per insert increases from 0.5 to $1.00 \mathrm{~mm}$ for tool no. 1 (Figs. 6, 7); comparing feed rates 1.00 and $1.50 \mathrm{~mm}$ increment of radius makes up 5.90\%; the lowest different is observed between the highest feeds per insert-5.04\%. Results of intensity of edge recession $i_{\rho}$ prove all the assumptions (Fig. 8). 

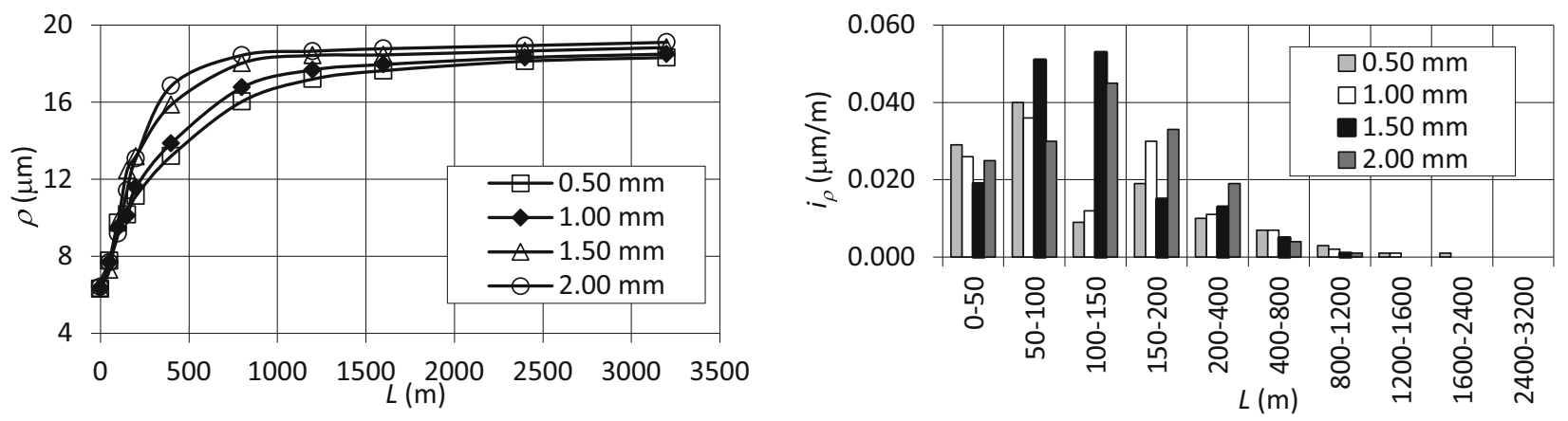

Fig. 6 Influence of feed per insert $f_{\mathrm{z}}(\mathrm{mm})$ on cutting edge radius $\rho(\mu \mathrm{m})$ and on the intensity of edge recession $i_{\rho}(\mu \mathrm{m} / \mathrm{m})$ of tool no. 1
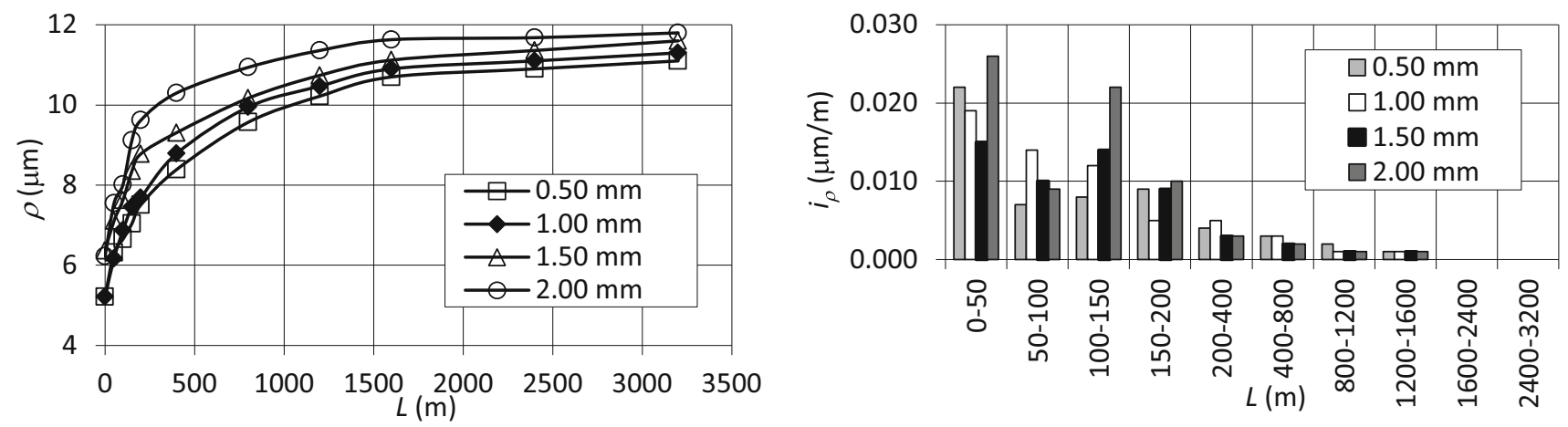

Fig. 7 Influence of feed per insert $f_{\mathrm{z}}(\mathrm{mm})$ on cutting edge radius $\rho(\mu \mathrm{m})$ and on the intensity of edge recession $i_{\rho}(\mu \mathrm{m} / \mathrm{m})$ of tool no. 4

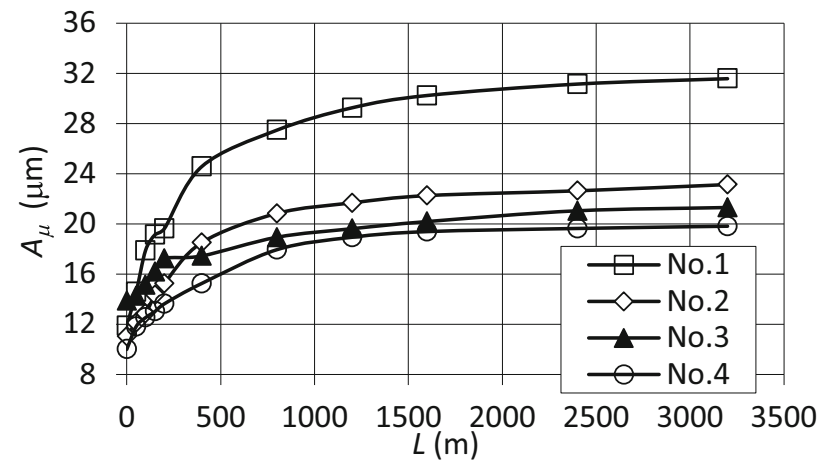

(a)

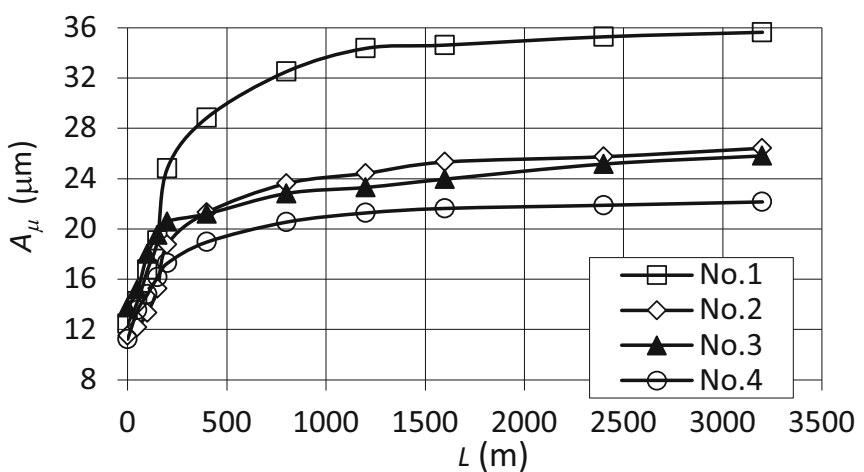

(b)

Fig. 8 Influence of feed per insert on edge recession $A_{\mu}(\mu \mathrm{m}): \mathbf{a} f_{\mathrm{z}}=0.50 \mathrm{~mm}, \mathbf{b} f_{\mathrm{z}}=2.00 \mathrm{~mm}$

Obtained results prove the statements of cutting theory: on increasing average thickness of chip in wood milling process, edges of tool wear out more intensively [19, 24]. It is estimated that when chip thickness is lower, clearance surface of tool wears more intensively, influence of frictional force which acts to the rake surface is negligible, because contact sliding path of clearance surface is bigger than contact of rake surface. On increasing the thickness of chip, friction force and contact length increase.

The highest values of cutting power $P$ and intensity of variation of cutting power coefficient $i_{\mathrm{p}}$ are achieved testing toll no. 1; such a tendency is seen for all feeds per insert (Fig. 9).

In the first period of milling until $200 \mathrm{~m}$ of cutting length edges of all tools undergo intensive crumbling of edges, therefore cutting power increases in average by $20 \mathrm{~W}$. This period gives the highest increment in cutting edge radius and the intensity of edge recession. Next period of milling from 200 until $400 \mathrm{~m}$ shows stable process, because edges of all tools decrease gradually from crumbling wear to low wear phase. Not linear increment of cutting power is observed in the cutting length $400-800 \mathrm{~m}$; 


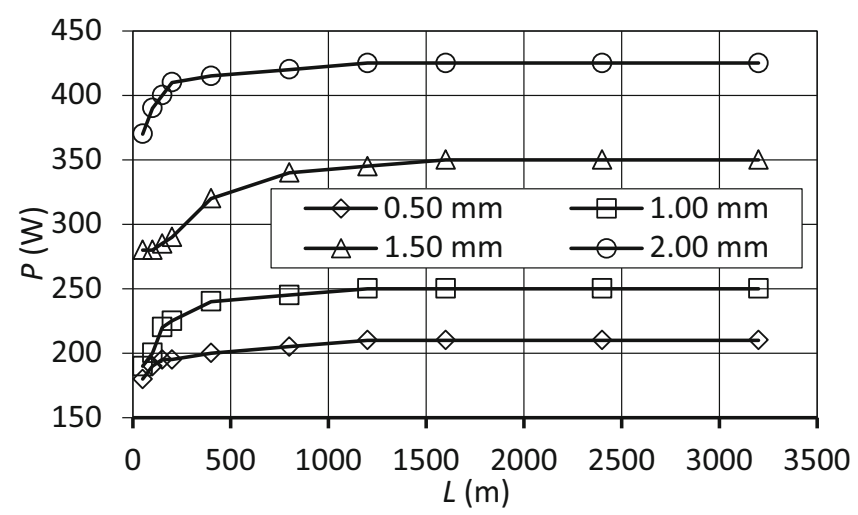

(a)

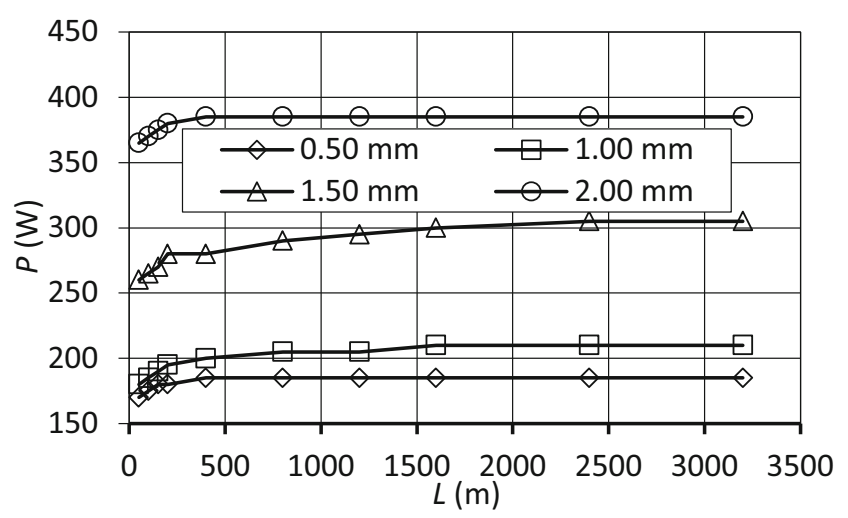

(b)

Fig. 9 Influence of feed per insert $f_{\mathrm{z}}(\mathrm{mm})$ on cutting power $P(\mathrm{~W})$ : a tool no. 1 , b tool no. 4

edges of tools reach uniform wear (no crumbling of edges) phase. Section from 800 to $1600 \mathrm{~m}$ highlights slight but linear increment of cutting power. Difference of cutting power in the $1600 \mathrm{~m}$ of cutting length when feed per insert $0.50 \mathrm{~mm}$ : nos. 1 and $2-7.14 \%$, nos. 1 and $3-9.52 \%$, the highest difference nos. 1 and $4-11.9 \%$. When increased feed per insert until $2.00 \mathrm{~mm}$ difference of cutting power has other values: nos. 1 and $2-4.71 \%$, nos. 1 and $3-$ $8.24 \%$, the highest difference nos. 1 and $4-9.41 \%$. These results prove that all milling tools after $1600 \mathrm{~m}$ of cutting length move to the monotonic phase of wear [25]. The last period tested in this study (1600-3200 m) shows monotonic wear; values are slightly increased for every feed per insert.

\section{Conclusion}

In this study, the technical characteristics of four standard tools from different suppliers have been studied by means of cutting edge radius, edge recession, cutting power, feed per insert. It is shown that chemical composition of tool material and heat treatment schedule has great impact on the tool edge wear. The highest wear resistance was shown testing tools made of CT01M-LA2 steel (no. 4); tools made of high-alloyed tool steel 8 X6HФT (no. 1) have presented the highest cutting edge radius and edge recession in each type of test as compared with other tools made of highspeed tool steels Z80WCV 18-04-01/18-0-1 and HS 18-0-1 (nos. 2 and 3), respectively. High-speed tool steels possess more alloying elements, which increases hardness, strength and wear resistance of tools.

This study revealed that wear of tool edges is more intensive increasing feed per insert from 0.5 to $2.00 \mathrm{~mm}$ : inverse dependence was defined as compared with influence of cutting speed. It is determined that increasing feed per one insert cutting power and cutting edge radius increases as well.

Based on the microstructural, chemical, mechanical analysis and wear performance of tools, high speed tool steel CT01M-LA2 (tool no. 4) was chosen to be the most suitable steel among those tested for making of oak wood cutting tool.

\section{References}

1. Strehler C, Parlinska-Wojtan M, Blugan G, Speisser B, Ehrle B, Aneziris CG, Graule T, Kuebler J (2011) Influence of intergranular phases on edge integrity of $\mathrm{Si}_{3} \mathrm{~N}_{4} / \mathrm{SiC}$ wood cutting tools. J Eur Ceram Soc 31:2711-2719

2. Hernádez-Castaneda JC, Sezer HK, Li L (2011) The effect of moisture content in fibre laser cutting of pine wood. Opt Lasers Eng 49:1139-1152

3. Horman I, Busuladžić I, Azemović E (2014) Temperature influence on wear characteristics and blunting of the toll in continuous wood cutting process. Procedia Eng 69:133-140

4. Vobrouček J (2015) The influence of milling tool geometry on the quality of machined surface. Procedia Eng 100:1556-1561

5. Strehler C, Blugan G, Ehrle B, Speisser B, Graule T, Kuebler J (2010) Influence of sintering and sintering additives on the mechanical and microstructural characteristics of $\mathrm{Si}_{3} \mathrm{~N}_{4} / \mathrm{SiC}$ wood cutting tools. J Eur Ceram Soc 30:2109-2115

6. Costes JP, Larricq P (2002) Towards high cutting speed in wood milling. Ann Forest Sci 59:857-865

7. Porankiewicz B, Iskra P, Jozwiak K, Tanaka C, Zborowski W (2008) High speed steel tool wear after wood milling in the presence of high temperature tribochemical reactions. BioResources 3(3):838-858

8. Bendikiene R, Keturakis G, Pilkaite T, Pupelis E (2015) Wear behaviour and cutting performance of surfaced inserts for wood machining. Strojniški Vestnik J Mech Eng 61(7-8):459-464

9. Faga MG, Settineri L (2006) Innovative anti-wear coatings on cutting tolls for wood machining. Surf Coat Technol 201:3002-3007

10. Gilewicz A, Warcholiński B, Myśliński P, Szymański W (2010) Anti-wear multilayer coatings based on chromium nitride for wood machining tools. Wear 270:32-38 
11. Aguilera A, Méausoone PJ, Rolleri A, Barros JL, Burgos F, Aguilar C (2016) Advances on indirect methods to evaluate tool wear for Radiata pine solid wood molding. Wear 350-351:27-34

12. Hosseini A, Kishawy H (2014) Cutting tool materials and tool wear. In: Davim JP (ed) Machining of titanium alloys. Springer, Berlin, pp 31-56

13. Bendikiene R, Keturakis G (2016) The effect of tool wear and planning parameters on birch wood surface roughness. Wood Res 61(5):791-798

14. Guo X, Ekevad M, Grönlund Marklunf B, Cao P (2014) Tool wear and machined surface roughness during wood flour/polyethylene composite peripheral up-milling using cemented tungsten carbide tools. BioResources 9(3):3779-3791

15. Beer P (2005) In situ examinations of the friction properties of chromium coated tools in contact with wet wood. Tribol Lett 18(3):373-376

16. Porankiewicz B, Iskra P, Sandak J, Tanaka C, Jóźwiak K (2006) High-speed tool wear during cutting in the presence of hightemperature corrosion and mineral contamination. Wood Sci Technol 40:673-682

17. Bledzki AK, Faruk O (2005) Microcellular wood fiber reinforced PP composites: cell morphology, surface roughness, impact, and odor properties. J Cell Plast 41(6):539-550

18. De Meijer M, Haemers S, Cobben W, Militz H (2000) Surface energy determination of wood: comparison of methods and wood species. Langmuir 16(24):9352-9359
19. Richter K, Feist WC, Knaebe MT (1995) The effect of surface roughness on the performance of finish. Part 1. Roughness characterization and stain performance. For Prod J 45(7/8):91-96

20. Porankiewicz B, Sandak J, Tanaka C (2005) Factors influencing steel tool wear when milling wood. Wood Sci Technol 39:225-234

21. Pałubicki B, Szulc M, Sandak J, Sinn G, Orłowski K (2014) A method and device for $3 \mathrm{~F}$ recognition of cutting edge micro geometry. DRVNA Industrija 65(1):11-19

22. Abele A, Miončinskis U (2012) Parameter changes which characterize the wear of the cutting tool in the milling process of Aspen wood. Pro Ligno 8(3):74-88

23. Darmawan W, Rahayu I, Nandika D, Marchal R (2012) The importance of extractives and abrasives in wood materials on the wearing of cutting tools. BioResources 7(4):4715-4729

24. Laszewicz K, Górski L, Wilkowski J (2013) Long-term accuaracy of MDF milling process-development of adaptive control system corresponding to progression of tool wear. Eur J Wood Wood Prod 71(3):383-385

25. Darmawan W, Gottlöber C, Oertel M, Wagenführ A, Fisher R (2011) Performance of helical edge milling cutters in planning wood. Eur J Wood Prod 69:565-572 